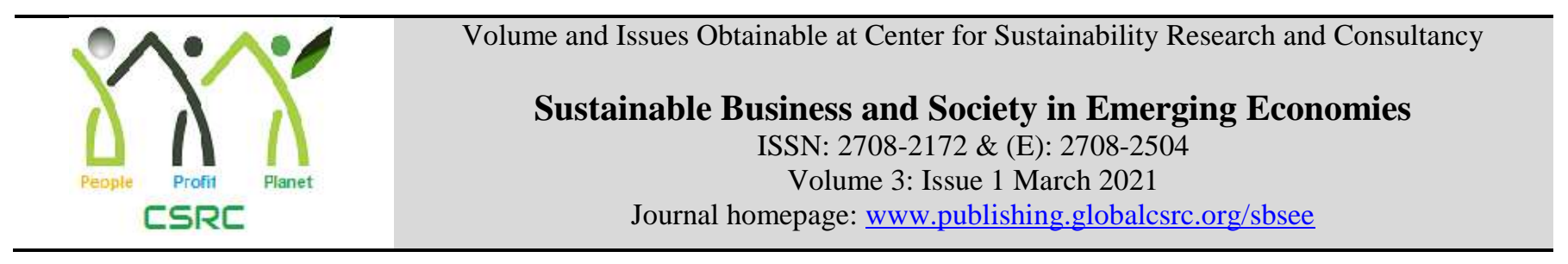

\title{
Impact of Demographic Variables on Economic Growth in South Asian Countries: A Panel Data Analysis
}

Nisar Ahmad, Assistant Professor, Department of Economics, University of Sargodha, Pakistan Sara Nayyab, MPhil Scholar (Economics), Allama Iqbal Open University Islamabad, Pakistan

Corresponding author's email address: drnisarahmad25@gmail.com

\begin{tabular}{l}
\hline ARTICLE DETAILS \\
\hline History \\
Revised format: Feb 2021 \\
Available Online: Mar 2021
\end{tabular}

Keywords:

Life expectancy, Fertility rate, Economics growth, South Asian Countries

\section{JEL Classification:}

CO1, J0O

\section{\begin{tabular}{l} 
ABSTRACT \\
\hline Purpose: The present study estimates the impact of important
\end{tabular} demographic variables upon the economic growth in the selected four South Asian countries. These countries are Bangladesh, India, Pakistan and Sri-Lanka.}

Design/Methodology/Approach: The fully modified ordinary least square method is used to estimate the relationship among demographic variables and economic growth. Fertility rate and life expectancy are used as demographic variables whereas GDP is used to indicate the economic growth.

Findings: Results explain that life expectancy and total fertility rate have significant impact upon the economic growth in case of these four selected South Asian countries. For example, one unit increase in total fertility rate depresses the economic growth by 0.106 units. However, economic growth is accelerated by 0.196 units due to one year increase in life expectancy.

Implications/Originality/Value: It is recommended to policy makers to concentrate on the health issues of the people as life expectancy has positive impact on the economic growth. Further, it is inevitable to lower down the fertility rate to achieve economic growth in these countries.

(C) 2021 The authors, under a Creative Commons Attribution- Non

Commercial- 4.0

Recommended citation: Ahmad, N. and Nayyab, S. (2021). Impact of Demographic Variables on Economic Growth in South Asian Countries: A Panel Data Analysis. Sustainable Business and Society in Emerging Economies, 3 (1), 49-58

\section{Introduction}

Economic growth is based on multiple factors and their interconnections with each other. Land, labor, capital and organization are prime mover of economic growth in traditional economic theories. However, technological innovations and demographic transition has changed the production functions over time (Abdullah et al, 2015). Exchange rate, financial crises and investment are important determinants of economic growth (Manuk et al, 2015). Pravakr et al. (2008) emphasize that infrastructure is another important factor to affect the economic growth. Eggleston and Fuchs (2012) describe that life expectancy outcome into extended working and enhance economic growth. The age- 
structure has positive impact on economic growth (Choudhry \& Elhorst, 2010 and Uddin et al., 2016). The significance of population demography in determining the economic growth is consequential (Gideon et al, 2013). Economic and population growth nexus has three views. These views consider with special reference to negative population growth impact, positive population growth impact and indifferent population growth impact (Musa, 2015). However, analyzing the population economic growth nexus the two demographic natural variables i-e fertility rate and mortality are the decisive factors (Labran Hamza, 2015).

Total fertility and mortality rates are the intrinsic demographic variables. The declining trends in fertility and mortality are observed in USA. The decline in mortality rate is observed initially and then the fertility transition was occurred (Warran Thompson, 1929). Demographic transition is a process in which a country progress from backward agricultural economy to a modern state when a transition occur from high fertility to low fertility and low mortality (Dudley Kirk, 1996). Continual variation in the total fertility and mortality is characterized as demographic dynamics. Due to this continuous change in fertility and mortality rates, the dissemination in population growth across different age group is observed (Misbah Tanveer Choudhry, 2010).

The transition in birth and death rates are observed by Warran Thompson (1929) and this transition is described as demographic transition. The demographic transition process is a multi-step process and completes in four stages characterizing with different demographic features with eminent social, economic and educational impacts. Different countries are passing from different stages of demographic transition (Khalid et al, 2015). High mortality \& fertility rates in Afghanistan and Angola, high fertility and low mortality rates in African regions; low mortality \& fertility in South and East Asian regions and fertility below replacement level in Japan are observed. These rates are associated with four stages of demographic transition respectively. Further, the highly developed nations are in the fourth stage whereas developing world is in stage 2 and 3 of demographic transition (Khalid et al, 2015).

South Asian countries are passing through the demographic transition with population changing structure with productive population (15-64) as a prominent age group. India contributes 76 per cent in South Asian population. Pakistan's share in total South Asian population is 11 percent and Bangladesh share is nine percent (United Nations, 2009). Nepal and Sri-Lanka's population share in total South Asia's population is very low and it is two per cent and one per cent respectively during 2000-2012.

Due to fertility transition, population changing structure among different age groups is an indispensible determinative factor for economic and productivity growth. The bulging productive population relative to the dependent population is the demographic transition consequence. This expanded working age population share resulting in prospective opportunity of rapid economic growth and such type of opportunity is known as demographic dividend. Demographic transition affects the economic growth through increasing labor supply, physical capital, human resource investment, labor productivity and savings (Misbah Tanveer Choudhry, 2010). Due to systematic diversity and institutional differences, demographic dividend and benefits differs across the countries. Best policy environment in the economy is required to avoid the failure of demographic dividend prospect.

Population changing structure is observed as fertility decline due to fertility transition. During demographic dynamic, young dependency ratio (0-14), productive population ratio (15-64) and the old dependency ratio (65+) become the important determinants of economic growth. During the demographic dynamic, the labor supply increases due to the high ratio of productive population (15-64) which required the essential educational policy structure and labor market reforms to increase the absorbing capacity of the labor market (Misbah Tanveer Choudhry, 2010). The demographic transition process and its out turn on the population changing distribution of a country is a significant and comprehensive for the economy. The demography of an economy provides best perception in the policy formulation to cash projects for future planning. Demographic transition process can support the 
creation of best policy structure for achieving the supreme gains from demographic dividend.

The accelerated economic growth is associated with demographic dividend while the depressed economic growth is related with demographic debt during demographic transition. Similarly, population changing structure is a factor of economic growth; however, it needs proper investment in education and job creation which will minify the economic challenges. We have examined the impact of demographic variables on economic growth in four South Asian countries in this study.

\section{Review of Literature}

Sher et al (2013) estimate the impact of population upon economic growth in Pakistan for the period 1975-2014 using ARDL approach. They included human resource development and term of trade as control variables in the econometric model and found that their impact is positive upon economic growth in Pakistan. In case of India, Musa (2015) concludes that population growth has a positive impact on economic growth during the time period 1980-2013. He explains that urbanization, population growth and employment are the major determinants of GDP in Indian.

Shahjahan et al (2015) and Abdullah et al (2015) test the Malthusian pessimistic population theory in Bangladesh and supported Malthusian view empirically. Shahjahan et al (2015) estimate a negative impact of population upon economic growth in Bangladesh. It proves Malthusian pessimistic population theory in most developing countries like Bangladesh. It is due to insufficient dynamic labor market, decreasing ratio of productive population, vicious circle of poverty and absence of sustainable development in Bangladesh. Abdullah et al (2015) observe the increasing population growth trend in Bangladesh during 1980-2005 and estimate the impact of increasing trend of population on economic growth. It is concluded that 1.87 per cent decline in economic growth occurs due to one per cent increase in population in Bangladesh. This again supports Malthusian school of thought in Bangladesh.

Menik et al (2014) exercise the effect of demographic transition process on economic development in Sri-Lanka for the time period from 1963 to 2007. Infant mortality rate and population growth rate are taken as demographic variables to estimate their impact on economic growth. They conclude that a unit increase in population growth leads to two units increase in GDP and GDP rate is depressed by 0.074 per cent due to one unit increase in infant mortality rate. However, one per cent increase in labor force assists the economic growth by 0.138 per cent.

Quamrul et al (2013) explain the fertility reduction effect on economic growth in Nigeria during 2010. They observe 0.5 per cent declining trend in fertility rate in Nigeria and this reduction in fertility rate accelerates the GDP per capita by 11.9 per cent. They conclude that fertility reduction accelerates economic growth and reduce the poverty in Nigeria. Further, it reduces the child dependency ratio which stimulated the domestic savings and investment. The reduction in fertility is also associated with human development by approving the better education and health facilities.

Jacob et al. (2016) explore the association between population growth and economic growth in 30 populated countries in the world for time period (1960-2013) in the long run period. They find that population growth and economic growth are co-integrated. Kremer's idea that population growth positively act as an agitator to economic growth in long run is confirmed in his study. Temitope et al (2013) find the population dynamic impact on economic growth in 35 African regions during 19702005. Mortality and fertility rates are used as demographic variables. The results explain that fertility rate has a negative impact on economic growth while mortality put positive impact on economic growth. High fertility and the associated negative impact of population growth put pressure on infrastructure, better education facilities became scarce, health and housing facilities provide limited access for major population portion with low per capita income enhanced the social and economic problems in Africans regions. To gain quick progress in 35 African countries, an instant reduction in fertility is pre-requisite.

Labran Hamza (2015) confirms the interdependence between population and economic growth by taking 
the panel data in 30 developing regions of Asia, Africa and Latin America using panel co-integration technique. Sandip et al (2016) explore the interrelationship between urban population and economic growth in South Asian countries by incorporating the GDP as dependent variable while urban population as independent variable during 1980-2014 with panel co integration. The included South Asian countries are India, Pakistan, Bhutan, Nepal, Sri-Lanka and Bangladesh. Results find the long run relationship between economic growth and urban population growth. Further, the long run causality is found from urban population growth to GDP. Sijia Song (2013) explains the impact of demographic changes on economic growth in 13 Asian countries (East, South and Southeast Asian regions) during 1961 to 2009. It is concluded that one per cent increase in total population depress the economic growth by 1.707 per cent and one per cent increase in working age population lead to economic growth by 1.264 per cent. Furthermore, one percent increase in young dependency ratio depresses the economic growth by 0.53 per cent and one percent increase in old dependency ratio lead to 0.217 per cent increase in economic growth in these countries. Finally, one per cent increase in productive population accelerates the economic growth by 1.457 per cent.

\section{Data and Methodology}

To study the impact of demographic variables upon the economic growth of South Asian Countries, balanced panel data of GDP growth, total fertility rate, life expectancy and gross capital formation for the period 1976-2017 from World Bank database is used. The description of variables is given below:

\section{Gross Domestic Product Growth}

The gross domestic product growth is used as the dependent variable. The manufacturing of final goods and services in specific time period with the utilization of different factors of production with in a country is called gross domestic product (GDP). Within country its calculation is based on local currency and market prices while at aggregate level its calculation is based on US dollar. Its growth is based on annual percentage.

\section{Total Fertility Rate}

It is an important, core and natural demographic variable. This natural demographic variable change the entire population structure in an economy and it is inserted as an independent variable in this study. Total fertility rate is the total number of children birth by a woman during childbearing years but with the condition if she lives until the end of her childbearing life. The decline in fertility rate is responsible factor behind the first demographic dividend.

\section{Life Expectancy}

The second demographic variable included in this study is life expectancy at birth. Life expectancy at birth signifies the total number of years in which a new baby born will survive. Life expectancy is the existence of human capital in an economy in form of health. So this explanatory variable not only treated as natural demographic variable but also the representative factor of second demographic dividend.

\section{Gross Capital Formation}

Gross capital formation is included as a control variable in the panel model. It is also called as gross domestic investment. It is the disbursement on fixed assets and also incorporating the expenditures on changing level of inventories including stock of goods produced by the firms to meet the short term and unpredicted variations in the production and sale.

\section{Methodology}

The objective of this study is to determine the impact of demographic variables upon economic growth in case of panel co-integration and long run relationship. Co-integration analysis in panel context is conducted using three steps. In first step, the order of integration in the fertility rate, life expectancy, GDP growth and gross capital formation is identified using the panel unit root tests. In the second step, 
panel co-integration is applied to find the long relationship among fertility rate, life expectancy, gross capital formation and gross domestic product. Thirdly, the long run parameters are estimated by applying the panel FMOLS estimators. The logical investigation behind applying the modern panel approaches is that these non-stationary panels have intense significance in empirical research over several years. Panel unit root test are briefly described in the following lines.

\section{Panel Unit Root Tests}

In LLC test, we run ADF for cross-sections, run two auxiliary regressions and the standardization of residuals. Finally we run the pooled OLS regression of this form $\tilde{e}_{\mathrm{it}}=\rho \tilde{v}_{\mathrm{i}, \mathrm{t}-1}+\tilde{\varepsilon}_{\mathrm{it}}$ and null hypothesis is $\rho=0$. Further the LLC test will valid in case when T lies between 5 and 250 and $\mathrm{N}$ lies between 10 and 250 for small T the LLC test will lose the test power. The LLC test is restrictive in the sense that all cross-sections have unit root.

Im, Pesaran and Shin test is flexible than LLC as heterogeneous coefficients are allowed in this test. The null hypothesis is that all individual follow a unit root process rather than a cross-section and the alternative hypothesis allow that not all but some of the individual have unit-root. Unlike Levin, Lin and $\mathrm{Chu}$ test IPS test is not restrictive with respect to time period $\mathrm{T}$ and cross-section $\mathrm{N}$.

Fisher-PP test is based on $\mathrm{P}$ value which derived from unit-root-tests for each cross-section. The Fisher$\mathrm{PP}$ test approaches to chi-square distribution with $2 \mathrm{~N}$ degree of freedom with $\mathrm{T} \rightarrow \infty$ with finit $\mathrm{N}$. The beneficial aspect of Fisher-PP test over other tests it can be applicable for unbalanced panel data. So Fisher-PP test is more superior to LLC and IPS due to its application in unbalanced panel.

In 1932, Fisher developed the ADF Fisher $\chi^{2}$ test and in 1999 Maddala and Wua preferred this test statistics. The test statistics is non-parametric and having the properties of chi-square distribution. The following form of test statistic is used. $\lambda=-2 \sum_{i=1}^{N} \log _{\mathrm{e}} \prod i$. Here $\prod i$ represents the p-value of test statistic in terms of unit $i$.

\section{Panel Co-integration}

The panel co-integration is introduced by Pedroni (1999). Consider given equation to explain panel cointegration. $y_{i t}=a_{i}+\beta_{1 i} x_{1 i, t}+\beta_{2 i} x_{2 i, t}+\ldots \ldots . . .+\beta_{M i} x_{M i, t}+e_{i, t}$, Where $t=1 \ldots T ; i=1 \ldots N ; m=1 \ldots$ Here $\mathrm{T}$ is number of observations and $\mathrm{N}$ is number of cross-sectional units. Here $\mathrm{T}$ is 42 years from 1976-2017 and $\mathrm{N}$ is four cross-sectional units in the panel and these are four countries. While M represents the number of explanatory variables and $\mathrm{y}_{\mathrm{t}}$ is the dependent variable. $\mathrm{a}_{\mathrm{i}}$ is the fixed effect parameters which vary across each cross sectional units while $\beta_{1 \mathrm{i}}$ to $\beta_{\mathrm{Mi}}$ are the slope co-efficient's for Pakistan, India, Bangladesh and Sri-Lanka. Pedroni (1999 \& 2004) proposes two sets of statistics for panel co-integration. The first test statistic is based on the within-dimension approach and second is based upon the between dimension approach which include three statistics.

In 1998, kao used the average of ADF test statistics to test the hypothesis of no co-integration. McCoskey and kao suggest the ADF test with flexible approach in this sense that it allow to varying slopes and intercepts across cross-sections.

\section{Panel Co-Integration Estimation}

For estimating the panel co-integration parameters a number of methods have been developed but the most prominent and modern panel approach is Fully-Modified-Ordinary-Least-Squares (FMOLS). In the presence of stationary time series by applying the traditional panel approaches panel OLS, random effect and fixed effect may produce spurious results. To eradicate this problem of spurious results FMOLS incorporated to verify the long run relationship between variables. FMOLS is non-parametric and it overcomes the problem of endogeneity of the explanatory variables and auto-correlation of the residuals. The condition of running the FMOLS is that the data series should non-stationary and it must be stationary after taking the first difference and data series should be co-integrated after applying the panel 
co-integration tests. Then the long run relationship between variables must be identified by applying the FMOLS to avoid spurious results.

In analyzing the impact of demographic variables on economic growth in selected South Asian countries the following panel model is designed by incorporating the $\mathrm{i}$ and $\mathrm{t}$ as sub-script for each cross-sectional units and time period.

$\mathrm{GDP}_{\mathrm{it}}=\beta_{1 \mathrm{i}}+\beta_{2} \mathrm{FRT}_{\mathrm{it}}+\beta_{3} \mathrm{LFE}_{\mathrm{it}}+\beta_{4} \mathrm{GCF}_{\mathrm{it}}+\mu_{\mathrm{it}}$

Where: GDP is Gross-Domestic-Product and is dependent variable.

The independent variables are; FRT is Total Fertility Rate, LFE is Life Expectancy at Birth and GCF is Gross-Capital-Formation and used as a control variable.

\section{Results and Discussion}

Table 1 explains that GDP is stationary at first difference; however, it is found non-stationary at level. It is described that these results are significant at five per cent level of significance.

Table 1: Panel Unit-Root Test for GDP

\begin{tabular}{|l|c|c|c|c|c|}
\hline \multirow{2}{*}{ Method } & \multicolumn{2}{|c|}{ At Level } & \multicolumn{2}{c|}{ At First Difference } & \multirow{2}{*}{$\begin{array}{l}\text { Order of } \\
\text { Integration }\end{array}$} \\
\cline { 2 - 5 } & T-Statistic & P-Value & T-Statistic & P-Value & I $(1)$ \\
\hline LLC & 92.116 & 1.000 & -107.972 & 0.000 & $\mathrm{I}(1)$ \\
\hline IPS & 1.9576 & 0.974 & -92.247 & 0.000 & $\mathrm{I}(1)$ \\
\hline ADF-Fisher $\chi^{2}$ & 1.5673 & 0.991 & 533.256 & 0.000 & $\mathrm{I}(1)$ \\
\hline PP-Fisher $\chi^{2}$ & 890.07 & 0.000 & 1053.56 & 0.000 & \\
\hline
\end{tabular}

Source: Author's Own Calculations

Table 2 explains that FRT is non-stationary at level but stationary at first difference. The null hypothesis that FRT having unit root is rejected at 5\% level of significance against the alternative hypothesis that FRT have no unit root because probability value is less than $5 \%$ for all panel unit-root tests. The results based on Automatic-Lag-Selection named SIC Schwarz-Info-Criterion. By comparing the probability value with the level of significance and concluded that the variable FRT is stationary on first difference I(1) not on level.

Table 2: Panel Unit-Root Test for FRT

\begin{tabular}{|l|c|c|c|c|c|}
\hline \multirow{2}{*}{ Method } & \multicolumn{2}{|c|}{ At Level } & \multicolumn{2}{c|}{ At First Difference } & $\begin{array}{l}\text { Order of } \\
\text { Integration }\end{array}$ \\
\cline { 2 - 5 } & T-Statistic & P-Value & T-Statistic & P-Value & I $(1)$ \\
\hline LLC & 12.406 & 1.000 & -35.556 & 0.000 & $\mathrm{I}(1)$ \\
\hline IPS & -0.8404 & 0.200 & -43.963 & 0.000 & $\mathrm{I}(1)$ \\
\hline ADF-Fisher $\chi^{2}$ & 10.402 & 0.237 & 79.435 & 0.000 & $\mathrm{I}(1)$ \\
\hline PP-Fisher $\chi^{2}$ & 115.38 & 0.000 & 73.682 & 0.000 & \\
\hline
\end{tabular}

Source: Author's Own Calculations

Table 3 explains that the variable LFE is likewise stationary at first difference. The results are based on five per cent level of significance.

Table 3: Panel Unit-Root for LFE

\begin{tabular}{|l|c|c|c|c|c|}
\hline \multirow{2}{*}{ Method } & \multicolumn{2}{|c|}{ At Level } & \multicolumn{2}{c|}{ At First Difference } & Order of \\
& T-Statistic & P-Value & T-Statistic & P-Value & Integration \\
\hline LLC & 198.612 & 1.000 & -97.063 & 0.000 & $\mathrm{I}(1)$ \\
\hline IPS & -0.4531 & 0.325 & -79.241 & 0.000 & $\mathrm{I}(1)$ \\
\hline ADF-Fisher $\chi^{2}$ & 6.461 & 0.595 & 269.224 & 0.000 & $\mathrm{I}(1)$ \\
\hline PP-Fisher $\chi^{2}$ & 724.441 & 0.000 & 899.081 & 0.000 & $\mathrm{I}(1)$ \\
\hline
\end{tabular}

Source: Author's Own Calculations 
Similarly, the results in table 4 explain that GCF is not found stationary at level. However, GCF is stationary at first difference. The level of significance is five per cent.

Table 4: Panel Unit-Root Test for GCF

\begin{tabular}{|l|c|c|c|c|c|}
\hline \multirow{2}{*}{ Method } & \multicolumn{2}{|c|}{ At Level } & \multicolumn{2}{c|}{ At First Difference } & Order of \\
& T-Statistic & P-Value & T-Statistic & P-Value & Integration \\
\hline LLC & 320.034 & 1.000 & -599.064 & 0.000 & $\mathrm{I}(1)$ \\
\hline IPS & 0.1294 & 0.551 & -298.306 & 0.000 & $\mathrm{I}(1)$ \\
\hline ADF-Fisher $\chi^{2}$ & 3.8198 & 0.873 & 266.408 & 0.000 & $\mathrm{I}(1)$ \\
\hline PP-Fisher $\chi^{2}$ & 260.924 & 0.000 & 390.618 & 0.000 & $\mathrm{I}(1)$ \\
\hline
\end{tabular}

Source: Author's Own Calculations

All the panel unit root tests (named Levin Lin \& Chu, Im, Pesaran \& Shin, ADF-Fisher $\chi^{2}$, PP-Fisher $\chi^{2}$ ) results showing that the variables GDP, FRT, LFE and GCF are stationary at first difference. The dataset is appropriate for further panel co-integration analysis. Table 5 explains the results of Pedroni Panel Cointegration Test.

Table 5a: Pedroni Panel Co-integration Test (Within Dimension)

\begin{tabular}{|l|c|c|c|c|}
\hline & T-Statistic & P-Value & Weighted T-Statistic & P-Value \\
\hline V-Statistic & -1.655 & .951 & -1.484 & .931 \\
\hline Rho-Statistic & -8.4042 & .000 & -4.675 & .000 \\
\hline PP-Statistic & -15.495 & .000 & -14.567 & .000 \\
\hline ADF-Statistic & 1.3618 & .9134 & 0.2849 & .6122 \\
\hline
\end{tabular}

Source: Author's Own Calculations

Table 5b: Pedroni Panel Co-integration Test (Between Dimensions)

\begin{tabular}{|l|c|c|}
\hline & T-Statistic & P-Value \\
\hline Rho-Statistic & -4.2130 & .0000 \\
\hline PP-Statistic & -17.4976 & .0000 \\
\hline ADF-Statistic & 1.0737 & .8585 \\
\hline
\end{tabular}

Source: Author's Own Calculations

Table 6 exhibits that null hypothesis of no co-integration against the alternative hypothesis of existing co-integration at $5 \%$ level of significance is rejected. The probability value is 0.041 which is less than $5 \%$. We concluded that Kao panel co-integration test exhibits that there exist co-integration among the variable GDP, FRT, LFE and GCF. The pedroni and kao panel co-integration test results in table 5 and table 6 based on Automatic-Lag-Selection based on AIC.

Table 6: Kao Panel Co-integration Test

\begin{tabular}{|l|c|c|}
\hline & T-Statistic & P-Value \\
\hline ADF & 1.73 & 0.041 \\
\hline Residual variance & 5.48 & \\
\hline HAC variance & 0.50 & \\
\hline
\end{tabular}

Source: Author's Own Calculations

\section{Panel Fully-Modified-Ordinary-Least-Squares (FMOLS)}

The data analysis in panel unit-root and panel co-integration exhibited that all variables are of integrated order I(1) and panel co-integration approach indicated that GDP, FRT, LFE and GCF are co-integrated in long run. This panel unit-root and panel co-integration analysis exhibited that the dataset is appropriate for further FMOLS analysis in order to obtain the long-run and efficient estimates. So we precede the analysis by applying the FMOLS because the pre-requisite conditions for applying the FMOLS have fulfilled. These pre-requisite conditions are reproduced. 
- The variables must stationary at first difference I(1). The panel unit-root tests empirically indicate that GDP, FRT, LFE and GCF are I (1).

- The variables must be co-integrated in long run. The pedroni and kao panel co-integration approach empirically exhibited that dependent variable GDP and independent variables FRT, LFE and GCF are co-integrated in the long-run.

- For applying the FMOLS two important conditions have empirically proved so the longrun estimates have obtained in this panel study by applying the panel FMOLS approach.

- The FMOLS become efficient estimates for panel data. This study consists of panel study by incorporating the four cross-sections Pakistan, India, Bangladesh and Sri-Lanka.

FMOLS identifies the long run relationship among the dependent and independent variables. So by applying the FMOLS the long-run relationship among GDP, FRT, LFE and GCF is identified.

The results of FMOLS estimators are given in table 7.

Table 7: Results of FMOLS Estimators

\begin{tabular}{|c|c|c|}
\hline Variables & FMOLS Estimators & P Value \\
\hline FRT & -0.106 & 0.000 \\
\hline LFE & 0.196 & 0.010 \\
\hline GCF & 0.023 & 0.000 \\
\hline
\end{tabular}

Source: Author's Own Calculations

$5 \%$ level of Significance

Results explain that the life expectancy and gross capital-formation have positive impact on GDP growth and this impact is significant. However, it is found that fertility rate negative related with economic growth of these countries. It means that fertility rate and life expectancy are significant demographic variables and have impact on the economic growth. It is concluded that fertility rate, life expectancy and gross capital formation are the long run determinants of economic growth in South Asian countries.

\section{Conclusion and Policy Recommendations}

The study estimates the long run impact of demographic variables upon economic growth in four south Asian countries Bangladesh, India, Pakistan and Sri-Lanka with panel data for the period 1976-2017. Panel unit root tests of LLC, IPS, ADF-Fisher $\chi^{2}$ test and Fisher-PP $\chi^{2}$ test are used to find the order of integration of each variable. Pedroni and kao panel co-integration is applied to test the long relationship among the variables and long run parameters are estimated by applying the panel FMOLS estimators. Total fertility rate, life expectancy and gross-capital-formation have significant impact on economic growth in these selected south Asian countries. Total fertility rate has negative and significant impact on economic growth. Life expectancy has positive and significant impact on economic growth. Further, positive impact of gross-capital-formation on economic growth is empirically verified in these selected south Asian countries.

The empirical evidences show that the fertility rate has negative impact on economic growth in these four south Asian countries. For achieving the economic development in south Asian countries, it is inevitable to lower the fertility rate in these four countries. Due to high fertility rate, there is huge economic burden on the productive population (15-64) although this productive population is in bulge in these south Asian countries. But this working age population (15-64) is facing the serious economic challenges (unemployment and underemployment). Government is also suggested to concentrate on the health issues of the people as life expectancy is found to have positive impact on the economic growth. Healthy people are able to contribute in economic growth of country. 


\section{References}

Abdullah, T. S. (2015). The effect of increase in population on economic growth of Bangladesh. Developing Countries Studies. 5(17) 87-94.

Breitung, J. (2000). The Local Power of Some Unit Root Tests for Panel Data. in B. Baltagi (ed.), Nonstationary Panels, Panel Cointegration, and Dynamic Panels, Advances in Econometrics, 15, 161-178, Elsevier Science.

Choi, I. (2001). Unit Root Tests for Panel Data. Journal of International Money and Finance. 20, 249272.

Choudhry, M. T. and Elhorst, J. P. (2010). Demographic Tansition and Economic Growth in China, India and Pakistan. Economic Systems, 34 (2), 218-236.

Ecevit, E. (2013). The impact of life expectancy on economic growth: panel co-integration and causality analysis for OECD countries. The International Journal Of Social Sciences. 16(1) 1-14.

Eggleston, K. N. and Fuchs, V. R. (2012). The New Demogrpahic Transition: Most Gains in Life Expectancy now Realized Late in Life. Journey of Economic Perspectives, 26 (3), 137-156.

Gideon K. T., Gachanja, P., and Obere, A. (2013) The impact of population change on economic growth in Kenya. International Journal of Economics and Management Sciences. 2 (6), 43-60

Hadri, K. (2000). Testing for Unit Roots in Heterogeneous Panel Data. Econometrics Journal. 3, 148161.

Hamza, L. (2015). Panel data analysis of population growth and it implication on economic growth of developing countries. Proceedings Of The International Symposium On Emergins Trends. 3(5) 114.

Im K.S., M.H. Pesaran (2003). On the Panel Unit Roots Testing Using Nonlinear Instrumental Variables. working paper. http://www.econ.cam.ac.uk/faculty/pesaran/.

Jacob Pegou Sibe, Cesaire Chiatchoua and Marie Noel Megne (2016) The Long Run Relationship between Population Growth and Economic Growth: a Panel Data Analysis of 30 of the most Populated Countries of the World. Análisis Económico. 77 (XXXI)

Khalid Iqbal, N. Y. (2015). Impact of demographic transition on economic growth of Pakistan. Journal of Finance And Economics. 3(2) 44-50.

Kirk, D. (1996). Demographic Transition Theory. Population Studies. 50361-387.

Levin, A., C.F. Lin and C.S.J. Chu (2002). Unit root tests in panel data: asymptotic and finite-sample properties. Journal of Econometrics. 108, 1-24.

Li, Y. (2015). The relationship between fertility rate and economic growth in developing countries. Lund University, School Of Economics And Management, Master Thesis. 1-93.

Maddala, G. and S. Wu (1999). A Comparative Study of Unit Root Tests and a New Simple Test. Oxford Bulletin of Economics and Statistics. 61, 631-652.

Manuk Ghazanchyan, J. G. (2015). A new look at the determinants of growth in Asian countries. International Monetary Fund. 1-33.

Menike, D. H. (2014). The impact of demographic transition on the economic growth and development in Sri-Lanka. Indian Journal Of Research In Management, Business And Social Sciences. 21(21) $1-5$.

Parvakar Sahro, R. K. (2008). Economic growth in south Asia: Role of infrastructure. WORKING PAPER SERIES 2008, Institute Of Economic Growth, University Of Delhi. 1-35.

Quamrul H.Ashraf, D. N. (2013). The effect of fertility reduction on economic growth. Population And Development Review. 39(1).

Sandip Sarker, A. K. (2016). Urban population and economic growth: south Asia perspective. European Journal Of Government And Economics. 5(1) 67-75.

Shahjan Ali, K. J. (2015). An empirical analysis of population growth on economic development: The case study of Bangladesh. International Journal Of Economics, Finance And Management Sciences. 3(3) 252-259.

Sher Ali, A. A. (2013). The impact of population growth on economic development in Pakistan. MiddleEast-Journal Of Scientific Research. 8(4) 483-491. 
Song, S. (2013). Demographic changes and economic growth: Empirical evidence from Asia. Illinois Wesleyan University Economics Department. 1-35.

Temitope Sada Akintunde, P. A. (2013). Population dynamics and economic growth in sub-saharanAfrica. Journal Of Economics And Sustainable Development. 4(13) 148-157.

Thompson Warren S. (1929). Population. American Journal of Sociology. 34, 959-975

Uddin, G. A., Alam, K. and Gow, J. (2016). Population Age Structure and Savings Rate Impacts on Economic Growth: Evidence from Australia. Economic Analysis and Policy, 52, 23-33.

United Nations (2009) World Population Prospects: The 2008 Revision. New York: 2009b. Data online at http://esa.un.org/unpp/index.asp 